localized instance arose in 1965, when Rutgers University historian Eugene

Free Speech and Liberal Education: A Plea for Intellectual Diversity and Tolerance, Donald Downs, Cato Institute, 2020, pp. 250, \$24.95 hardbound.

\section{In Defense of Free Speech on Campus}

\section{Glenn M. Ricketts}

Until the late 1960's, academic free speech issues, while intensely controversial, were also fairly straightforward. Most often, censorious attacks originated from sources external to the academy, usually reflecting the displeasure of morally affronted clergymen, politically aroused civic groups, or demagogic politicians. Thus, during the McCarthy era of the early 1950's, colleges and universities were heavily pressured to investigate or dismiss "subversive" professors suspected of secret Communist affiliations, and to implement "loyalty oaths" from their faculties, as many schools did. A similar, if more
Genovese publicly declared his support for a Viet Cong victory in the Viet Nam war. A public uproar ensued, with demands that Genovese be sanctioned or dismissed for the inflammatory comments. But in each of these and similar cases, academic leaders did not yield to public pressure, and responded by emphasizing the indispensability of free speech and academic freedom to the unfettered and open market of ideas that was so vital to higher educational institutions.

All of this changed dramatically in the late 1960's, however, when the most serious threats to academic freedom and free speech now emerged from within the academy: New Left student mobs shouted down speakers they did not want to hear, disrupted the classes of ideologically heterodox professors and physically assaulted other student groups with views that challenged their own. Academic leaders who had stoutly refused to yield to the anti-Communist zealots of the 1950's were often tepid or halting in defending free speech against the far more serious assaults from within the walls. And while the violence

Glenn M. Ricketts is professor of political science at Raritan Valley Community College, North Branch, NJ 08876, and public affairs director of the National Association of Scholars; ricketts@nas.org. He was the founding president of the NAS New Jersey state affiliate, and served for twenty years on the NAS board of directors. Ricketts last appeared in these pages with "Saving Remnants: Where Western Civ Thrives" (Summer 2019). 
eventually subsided, a culture of ideological conformity and intolerance of dissent remained and festered at many schools.

The problem is now in its fourth decade, and has metastasized throughout the academy, as Donald Downs illustrates in Free Speech and Liberal Education. An emeritus professor of political science, law, and journalism at the University of Wisconsin, Madison, Downs has pursued a parallel career as an intrepid, articulate, and effective public defender of freedom of speech, intellectual diversity, and traditional academic freedom in the American academy. He has written extensively in these areas, including several essays in these pages (“The Wisconsin Fight for Academic Freedom," Summer 2016), and in previous books such as Cornell 69: Liberalism and the Crisis of the American University (1999), Restoring Free Speech and Liberty on Campus (2005), and The Value and Limits of Academic Speech (2018, co-editor with Chris Suprenant).

In addition to innumerable articles in academic and popular venues, regular speaking engagements, panel discussions, and media presentations, Downs served as co-founder and leader of the Committee for Academic Freedom and Rights until his retirement in 2016. CAFAR is a non-partisan independent body of faculty in diverse disciplines which acted resolutely and publicly to safeguard free speech and academic inquiry at his UW/ Madison campus and other schools in the state. He has doggedly fought the good fight, as he continues to do in this career-capping book, his latest effort.

Downs begins with a compelling philosophical exegesis positing the academy as a polis, or "interactive community" devoted above all else to the pursuit of truth and the cultivation of intellectual virtues based pre-eminently on reason, but with due recognition of our fallibility in applying it, and the open and free exchange of ideas. Free speech, he posits, is the most crucial and indispensable component in this enterprise. He next devotes several chapters to a survey of the contemporary academic landscape and the multiple and often elusive factors which act to inhibit or suppress the open and free inquiry so vital to the pursuit of truth. He concludes with some practical suggestions of how individuals and organizations can act to educate colleagues and oppose campus censorship.

As Downs notes, the greatest threats to free speech, open debate and the marketplace of ideas are now ensconced within academic precincts, a many-sided reality that often reflects official institutional policies. 
Some aspects of the contemporary landscape hearken back to the late 1960's, especially the recent upsurge in orchestrated student mob violence against invited guest speakers or withdrawal of invitations tendered to others. But while the violence fifty years ago usually intimidated administrators or college presidents who often sat paralyzed in their offices, their present-day counterparts are just as likely to commend student thuggery, as did the President of Bryn Mawr College in December 2020, following a three-week "strike" during which protesters bullied and physically threatened faculty and other students who attempted to resume normal classroom instruction. ${ }^{1}$

But violent protests, while indeed deplorable, occur infrequently and are visible to the larger public. Far more significant, relentlessly vigilant, and largely invisible is the "shadow university," the immense bureaucratic juggernaut of Title IX investigators, "diversity and equity" offices, bias response teams, "hate crimes" hot lines, dormitory resident assistants, and civil rights compliance officersto name but a few-mid-level administrative wheels that spin furiously to purify their institutions of the racism, sexism, homophobia, etc. which they are convinced infest every corner, from the classroom to the cafeteria. As Downs illustrates, the "shadow university" represents a major segment of the immense bureaucratic expansion which has mushroomed within American higher education during the past several decades, especially increasingly ubiquitous and intrusive offices of Diversity and Equity. The University of Michigan, he writes, has added more than one-hundred new staff members to its "diversity" offices in the last several years, with Yale similarly adding dozens of new positions to an already burgeoning Office of Diversity and Inclusion.

Beyond the simple fact that such bureaucratic aggrandizement has contributed substantially to the ever-steepening costs of higher education, is the less visable reality that the "diversity" office, with an obsessive fixation on identity politics-race, gender, class, etc.-intrudes into virtually every aspect of institutional life: faculty and staff hiring, freshman orientation, dormitory activities, cafeteria menus, approval of student organizations, or potential guest speakers. Faculty members may find themselves directed to attend mandatory "cultural awareness" sessions, where they might be counseled to

1 Minnie Doe, "A Student Mob Took Over Bryn Mawr. The College Said Thank You," Quillette, December $27,2020$. 
adopt a more "inclusive" approach to their teaching; to be mindful of avoiding the use of "offensive" terminology in classroom discussions; to include "trigger warnings" in advance of discussing controversial topics; or admonished to avoid "microaggressions"-words, body language, or facial gestures through which hidden racist, sexist, or transphobic impulses are projected onto students. A few senior professors may have the security and resolve to boycott such sessions, but their untenured junior colleagues or increasingly numerous adjunct instructors certainly aren't likely to follow suit.

To all of this should be added the fact that students are encouraged to report-often anonymously-any perceived infractions or innocent remarks in classroom discussions, incautious comments posted on social media, and even op-eds written for mainstream media venues. Content in any of the venues can arouse suspicion in the Bias Response Team which is usually eager to pounce and "investigate."

The result is a climate of secrecy, surveillance, and censorship of a kind that produced the farcical but actual case of Laura Kipnis at Northwestern University several years ago, which
Downs cites as exhibit A of the surreal environment which increasingly pervades so many mainstream campuses. Kipnis ran afoul of what Daphne Patai had much earlier dubbed the "sexual harassment industry," a product of the militant, misanthropist feminism which had come to dominate academic women's studies programs in the 1990's. ${ }^{2}$ To her surprise, Kipnis found herself subject to a mandatory Title IX investigation, after she had published an article in the Chronicle of Higher Education criticizing the "sexual paranoia" and cult of victimhood which had prompted increasingly frivolous or unfounded accusations from female students. As a result, Kipnis herself became the object of a bizarre complaint when several students formally alleged that they had found her critique "hurtful" and threatening.

Under the mandatory federal Title IX guidelines then in force, the university was obliged to "investigate" although, as Patai's earlier book Heterophobia (2000) illustrated, the "sexual harassment industry" already long in place needed no prompting from the federal government. Having worked privately with several male students similarly accused, I can testify that the wheels of injustice move

2 Daphne Patai, Heterophobia: Sexual Harassment and the Future of Feminism (Rowman \& Littlefield, 2000). 
very swiftly and clandestinely to a guilty verdict (see my account in "The Tyranny of Allegations," $A Q$, Spring 2015). Kipnis was eventually exonerated and wrote a book about the episode entitled Unwanted Advances: Sexual Paranoia Comes to Campus (2017). Undergraduate males, needless to say, are often far less fortunate.

Contemporary colleges and universities, then, are ideological citadels, largely hostile to the open marketplace of ideas, which Downs argues ought to be their raison d'etre. Intellectual engagement is decidedly unwelcome and is probably much easier to find at the local sports bar. What can be done about this dismal state of affairs? Downs's first recommendation is simply to speak out, as he himself has often done, with the written and spoken word. That especially applies to senior professors who have tenure and who don't need to worry about any further promotions, but who often aren't interested if an issue doesn't affect them directly. Don't stand idly by if, for example, a colleague finds himself under fire for writing or saying something that runs afoul of campus "equity" administrators eager to placate hypersensitive or opportunistic complainants. Seek the support of like-minded colleagues, and stand together, especially if you are able to write open letters to your larger community of colleagues and seek to persuade them of the stake they also hold in safeguarding freedom of speech on campus.

Qualified faculty, following Downs's own example during his long career at Wisconsin, can design and offer courses on the First Amendment and how freedom of speech is understood and applied to public systems such as his own. And while Downs understandably believes that it is better to resolve issues of free speech and academic freedom in-house, defenders of academic free speech should also be aware of the positions taken by the American Association of University Professors (often not in the forefront, of course, but formally committed in its institutional mission), the American Civil Liberties Union (again, hold them to their own formal commitments), or FIRE, the Foundation for Individual Rights in Education. But even if Downs is understandably chary of involving state legislatures or other politicians-preservation of institutional autonomy is another of his central priorities-he also illustrates the ways in which legislators who support academic freedom might be usefully engaged in its defense.

But buoyed as I was by Downs's book, which I have to rate as a tour de force, I can't quite share his optimism, notwithstanding his commendable 
achievement. Since the book's publication last year, we have witnessed the explosion of "cancel culture" and a wave of unprecedented censorship, not only on college campuses, but in the larger society as well. The nursing school dean at the University of Massachusetts-Lowell, Leslie NealBoylan, was fired after sending an email to students including the sentence "everyone's life matters." Math professor Nathaniel Hiers was fired by the University of North Texas after he made a joke regarding microaggressions. University of Pittsburgh professor Norman Wang lost his title of program director of an important medical fellowship after writing in an academic journal that the medical field should not consider race when determining entrance to the field. ${ }^{3}$ Essayist Joseph Epstein, for thirty years a teacher in the English Department at Northwestern, found himself airbrushed out of existence, due to a satirical piece about incoming First Lady Jill Biden's pretentious use of the honorific "Doctor" before her name (she holds an Ed.D degree). And of course, the familiar roster of disinvited speakers continued on many college campuses, usually in response to student complaints about hurt feelings, insensitivity, etc., etc. The list of cancellations is, unfortunately, much longer. But while I can't share Donald Downs's greater optimism about the future, let no one for a moment think that he hasn't served the cause of free speech ably and nobly, far above and beyond the call of duty.

3 A longer list of 2020 cancellations can be found at Hannah Lalgie, "CANCELED: Counting down 2020's most shocking 'cancel culture' stories," Campus Reform, January 1, 2021. 